\title{
JAMINAN FIDUSIA DI INDONESIA (TATA CARA PENDAFTARAN DAN EKSEKUSI)
}

\author{
Junaidi Abdullah \\ Dosen Syariah dan Ekonomi Islam STAIN Kudus \\ Joen3di@yahoo.com
}

\begin{abstract}
Debtor when asking to financing financing institution (creditors) usually use the guarantee in the form of objects that move and things that do not move. When guaranteed in the form of moving objects, then creditors will bind him with fiducia warrant.. Fiducia warrant is the right guarantees for moving objects either exist or not exist and objects do not move especially the building could not be burdened by the yoke rights referred to in Law Number 4 of 1996 on the Rights of the yoke that remain in the mastery of a Warner fiducia warrant, as collateral for certain debt repayment, which provide the preferred position to the recipient fiducia warrant against other creditors. (Article 1 of Act No. 42 The year 1999 about fiducia warrant). Fiducia warrant must be made by deed autentik and must be registered in the registration office fiducia warrant and want to warranty certificate fiducia warrant. But sometimes the debtor does not perform its obligations to the debtor, so that the debtor has the right to execute the things that have been pledged fiducia warrant. But sometimes the implementation of the execution get resistance from the debtor, because the creditors with using services debt collector take force objects fiducia warrant without doing the negotiations even tear in the streets. For that the police can provide security services execution of parties willing to execute the object fiducia warrant.
\end{abstract}

Keywords : fiducia warrant, Registration procedures, execution 


\section{A. Pendahuluan}

Manusia merupakan makhluk yang selalu ingin mrncukupi segala kebutuhannya. Baik kebutuhan yang bersifat primer, sekunder maupun tersiernya atau bagi kebutuhan usahanya. Dalam memenuhi segala kebutuhannya tentu memerlukan dana. Dana tersebut bisa berasal dari pribadi manusia itu sendiri maupun dari pihak luar.

Bagi seseorang yang memerlukan dana dari pihak luar akan mengajukan pembiayaan (yang disebut gengan debitur) ke lembaga pembiayaan, baik lembaga pembiayaan bank atau lembaga pembiayaan non bank (yang disebut kreditur). Bagi pihak lembaga pembiayaan bank maupun non bank ketika menyetujui pembiayaan yang diajukan oleh nasabah pasti menginginkan adanya jaminan atau agunan.

Menurut Hartono Hadisoeprapto yang dimaksud dengan jaminan adalah "Sesuatu yang diberikan kepada kreditur untuk menimbulkan keyakinan bahwa debitur akan memenuhi kewajiban yang dapat dinilai dengan uang yang timbul dari suatu perikatan" (Hartono Hadisoeprapto, 2004: 50).

Benda jaminan yang di jaminkan ke lembaga pembiayaan (kreditur) biasanya berupa benda tidak bergerak berupa tanah dan bangunan yang bersertifikat hak milik maupun berupa benda bergerak berupa kendaraan bermotor maupun mobil. Untuk agunan yang dijaminkan berupa tanah atau bangunan, maka pihak lembaga pembiayaan (kreditur) mengikatnya dengan hak tanggungan dan benda bergerak di ikat dengan jaminan fidusia,

Untuk mendapatkan jaminan fidusia benda yang bergerak yang menjadi obyek jaminan harus didaftarkan ke kantor jaminan fidusia untuk mendapatkan sertifikat jaminan fidusia. Pendaftaran ini melalui elektronik.

Namun, kadangkala debitur yang menyerahkan jaminan fidusia tidak melaksanakan apa yang telah menjadi kesepakatan dengan kreditur. Bentuk wanprestasi atau ingkar janji ini bisa berupa tidak membayar hutang kepada kreditur, membayar tapi terlambat dan lain sebagainya. Tentu dengan adanya wanprestasi ini, menyebabkan kerugian bagi kreditur, sehingga membuat kreditur ingin mengeksekusi benda yang sudah di fidusiakan. 
Akan tetapi, pelaksanaan eksekusi yang dilakukan kreditur melalui jasa debt collector kadangkala menimbulkan masalah baru antara kreditur dengan debitur. Hal ini dikarenakan cara debt collector dalam mengeksekusi barang jaminan fidusia dengan cara kekerasan, intimidasi bahkan dengan cara kekerasan dengan cara merampas barang jaminan fidusia dijalan, hal inilah yang menimbulkan perlawanan dari pihak debitur.

Untuk itu agar terhindar dari perseteruan antara kreditur dan debitur yang berkepanjangan dan menimbulkan rasa ketidaknyamanan dan keamanan antara kedua belah pihak, kepolisian memberikan solusi berupa pengamanan eksekusi jaminan fidusia. Karena Kepolisian Negara Republik Indonesia merupakan alat negara yang bertugas dan berfungsi untuk memelihara keamanan dan ketertiban masyarakat, penegakan hukum, perlindungan, pengayoman, dan pelayanan kepada masyarakat.

Yang dimaksud dengan Pengamanan Eksekusi adalah tindakan kepolisian dalam rangka memberi pengamanan dan perlindungan terhadap pelaksana eksekusi, pemohon eksekusi, termohon eksekusi (tereksekusi) pada saat eksekusi dilaksanakan.

\section{B. Pembahasan}

\section{Jaminan Fidusia}

\section{a. Pengertian Fidusia dan Jaminan fidusia}

Kata fidusia berasal dari bahasa latin 'fiduciair' yang berarti 'secara kepercayaan' (R. Subekti, R. Tjitrosoedibio, 1994 : 42), kepercayaan yang dimaksud adalah kepercayaan yang diberikan dari debitur kepada kreditur sebagai pemindahan milik atau untuk suatu jaminan saja guna keperluan utang

Fidusia adalah pengalihan hak kepemilikan suatu benda atas dasar kepercayaan dengan ketentuan bahwa benda yang hak kepemilikannya dialihkan tersebut tetap dalam penguasaan pemilik benda Pasal 1 Undang-Undang Nomor 42 tahun 1999 tentang Jaminan Fidusia).

Sedangkan Jaminan fidusia adalah hak jaminan atas benda bergerak baik yang berwujud maupun yang tidak berwujud dan benda tidak bergerak khususnya bangunan 
yang tidak dapat dibebani hak tanggungan sebagaimana dimaksud dalam Undang-Undang Nomor 4 Tahun 1996 tentang Hak Tanggungan yang tetap berada dalam penguasaan Pemberi Fidusia, sebagai agunan bagi pelunasan utang tertentu, yang memberikan kedudukan yang diutamakan kepada Penerima Fidusia terhadap kreditor lainnya. (Pasal 1 Undang-Undang Nomor 42 tahun 1999 tentang Jaminan Fidusia).

Dari pengertian jaminan fidusia di atas, maka dapat unsur-unsur dari Jaminan Fidusia, meliputi:

1) Jaminan fidusia merupakan lembaga hak jaminan kebendaan

2) Obyek jaminan fidusia adalah benda bergerak dan benda tidak bergerak khususnya bangunan yang tidak dibebani dengan hak tanggungan

3) Benda yang menjadi objek jaminan fidusia tersebut adalah sebagai agunan atau jaminan untuk pelunasan suatu utang tertentu

4) Memberikan kedudukan yang diutamakan kepeda lembaga pembiayaan terhadap kreditur lainnya.

\section{b. Obyek dan Subyek Jaminan Fidusia}

Dari pengertian di atas, maka obyek jaminan fidusia meliputi:

1) Benda bergerak yang berwujud

2) Benda bergerak yang tidak berwujud

3) Benda tidak bergerak khususnya bangunan yang tidak dapat dibebani hak tanggungan

Sedangkan subyek dari jaminan fidusia adalah adalah mereka yang dapat mengikatkan diri dalam perjanjian jaminan fidusia, yang terdiri dari atas pihak debitur sebagai pemberi fidusia dan lembaga pembiayaan (kreditur) sebagai penerima fidusia . (Purwahid dan Kashadi, 2008 : 34-35).

Pemberi fidusia adalah orang perseorangan atau korporasi pemilik benda yang menjadi obyek jaminan fidusia. Sedangkan penerima fidusia adalah orang perseorangan atau korporasi yang mempunyai piutang yang pembayarannya dijamin dengan jaminan fidusia. 


\section{c. Proses terjadinya Jaminan fidusia}

Menurut undang-undang nomor 42 tahun 1999, Jaminan fidua terjadi melalui 2 tahapan :

1) Tahapan Pembebanan Jaminan Fidusia

Jaminan fidusia merupakan perjanjian ikutan dari suatu perjanjian pokok yang menimbulkan kewajiban bagi para pihak untuk memenuhi suatu prestasi. Pembebanan benda dengan jaminan fidusia dibuat dengan akta notaris dalam bahasa Indonesia dan merupakan akta jaminan fidusia. Terhadap pembuatan akta jaminan fidusia dikenakan biaya. Akta jaminan fidusia kurangnya memuat:

(a) Identitas pihak Pemberi dan Penerima fidusia

(b) Data perjanjian pokok yang dijamin fidusia

(c) Uraian mengenai Benda yang menjadi obyek Jaminan Fidusia

(d) Nilai penjaminan

(e) Nilai Benda yang menjadi obyek Jaminan Fidusia.

2) Tahapan Pendaftaran Jaminan Fidusia

Benda yang dibebani dengan jaminan fidusia wajib didaftarkan. Walaupun benda yang dijaminkan fidusia berada di luar wilayah republic Indonesia. Pendaftaran jaminan fidusia dilakukan pada Kantor pendaftaran fidusia. Permohonan pendaftaran jaminan fidusia dilakukan oleh penerima fidusia, kuasa atau wakilnya dengan melampirkan pernyataan pendaftaran jaminan fidusia. Pernyataan pendaftaran memuat :

(a) Identitas pihak Pemberi dan Penerima Fidusia

(b) Tanggal,nomor akta jaminan Fidusia, nama, tempat kedudukan notaris yang membuat akta Jaminan Fidusia

(c) Data perjanjian pokok yang dijamin fidusia

(d) Uraian mengenai Benda yang menjadi obyek Jaminan Fidusia

(e) Nilai penjaminan

(f) Nilai benda yang menjadi obyek Jaminan Fidusia.

Kantor pendaftaran fidusia mencatat jaminan fidusia dalam Buku Daftar Fidusia pada tanggal yang sama dengan tanggal penerimaan permohonan pendaftaran. Kantor pendaftaran fidusia menerbitkan dan menyerahkan kepada penerima fidusia pada tanggal yang sama dengan tanggal 
penerimaan permohonan pendaftaran. Sertifikat Jaminan Fidusia yang merupakan salinan dari Buku Daftar Fidusia memuat catatan tentang hal-hal persyaratan-persyaratan pendaftaran jaminan fidusia. Jaminan fidusia lahir pada tanggal yang sama dengan tanggal dicatatnya jaminan Fidusia dalam Buku Daftar Fidusia.

\section{d. Hapusnya Jaminan Fidusia}

Jaminan Fidusia hapus karena hal-hal sebagai berikut:

1) Hapusnya utang yang dijamin dengan fidusia

2) Pelepasan hak atas Jaminan Fidusia oleh Penerima Fidusia

3) Musnahnya Benda yang menjadi obyek Jaminan Fidusia.

Musnahnya benda yang menjadi obyek jaminan fidusia tidak menghapuskan klaim asuransi. Penerima fidusia memberitahukan kepada kantor pendaftaran fidusia mengenai hapusnya jaminan fidusia dengan melampirkan pernyataan mengenai hapusnya utang, pelepasan hak, atau musnahnya Benda yang menjadi obyek jaminan fidusia tersebut. Dengan hapusnya jaminan fidusia, kantor pendaftaran fidusia mencoret pencatatan jaminan fidusia dari Buku Daftar Fidusia. Kantor pendaftaran fidusia menerbitkan surat keterangan yang menyatakan Sertifikat jaminan fidusia yang bersangkutan tidak berlaku lagi.

\section{Tata Cara dan Biaya Pendaftaran jaminan Fidusia}

\section{a. Tata Cara Pendaftaran Jaminan Fidusia}

Jaminan fidusia merupakan salah satu pranata lembaga jaminan yang berada di Indonesia. Jaminan fidusia diperuntukan bagi benda bergerak seperti sepeda motor maupun mobil. Untuk mendapatkan jaminan fidusia, benda bergerak itu harus didaftarkan untuk diberikan surat atau akta jaminan fidusia. Permohonan pendaftaran jaminan fidusia diajukan oleh penerima fidusia, kuasa atau wakilnya kepada Menteri.

Undang-Undang Nomor 42 Tahun 1999 tentang Jaminan Fidusia menegaskan bahwa benda yang dibebani dengan jaminan fidusia wajib didaftarkan. Pendaftaran jaminan fidusia tersebut untuk memberikan kepastian hukum kepada para pihak yang berkepentingan. 
Tata cara pendafyaran jaminan fidusia telah diatur didalam Peraturan Pemerintah Nomor 86 tahun 2000 ientang Tata Cara Pendaftaran Jaminan Fidusia Dan Biaya Pembuatan Akta Jaminan Fidusia yang telah dirubah oleh Peraturan Pemerintah Nomor 21 tahun 2015 ientang Tata Cara Pendaftaran Jaminan Fidusia Dan Biaya Pembuatan Akta Jaminan Fidusia. Permohonan pendaftaran jaminan fidusia memuat:

(1) Identitas pihak Pemberi Fidusia dan Penerima Fidusia

(2) Tanggal, nomor akta Jaminan Fidusia, nama, dan tempat kedudukan notaris yang membuat akta Jaminan Fidusia

(3) Data perjanjian pokok yang dijamin fidusia

(4) Uraian mengenai benda yang menjadi objek Jaminan Fidusia

(5) Nilai penjaminan

(6) Nilai benda yang menjadi obyek Jaminan Fidusia.(pasal 3 Peraturan Pemerintah Nomor 21 tahun 2015 ientang Tata Cara Pendaftaran Jaminan Fidusia Dan Biaya Pembuatan Akta Jaminan Fidusia).

Permohonan pendaftaran Jaminan Fidusia diajukan dalam jangka waktu paling lama 30 (tiga puluh) hari terhitung sejak tanggal pembuatan akta Jaminan Fidusia. Permohonan pendaftaran Jaminan Fidusia yang telah memenuhi ketentuan atau memenuhi syarat-syarat memperoleh bukti pendaftaran.

Bukti pendaftaran paling sedikit memuat:

(1) Nomor pendaftaran

(2) Tanggal pengisian aplikasi

(3) Nama pemohon

(4) Nama Kantor Pendaftaran Fidusia

(5) Jenis permohonan

(6) Biaya pendaftaran Jaminan Fidusia .(pasal 5 Peraturan Pemerintah Nomor 21 tahun 2015 Tentang Tata Cara Pendaftaran Jaminan Fidusia dan Biaya Pembuatan Akta Jaminan Fidusia).

Pemohon melakukan pembayaran biaya pendaftaran jaminan fidusia melalui bank persepsi berdasarkan bukti pendaftaran. Pendaftaran jaminan fidusia dicatat secara elektronik setelah pemohon melakukan pembayaran biaya pendaftaran jaminan fidusia. 
Jaminan fidusia lahir pada tanggal yang sama dengan tanggal jaminan fidusia dicatat. Sertifikat jaminan fidusia ditandatangani secara elektronik oleh Pejabat pada kantor pendaftaran fidusia. Sertifikat jaminan fidusia dapat dicetak pada tanggal yang sama dengan tanggal Jaminan Fidusia dicatat.

Dalam hal terjadi kesalahan pengisian data dalam permohonan pendaftaran jaminan fidusia yang diketahui setelah sertifikat jaminan fidusia dicetak, penerima fidusia, kuasa atau wakilnya harus mengajukan permohonan perbaikan sertifikat jaminan fidusia kepada Menteri. Permohonan perbaikan sertifikat jaminan fidusia paling sedikit memuat :

(1) Nomor dan tanggal sertifikat Jaminan Fidusia yang akan diperbaiki

(2) Data perbaikan

(3) Keterangan perbaikan .(pasal 9 ayat 2 Peraturan Pemerintah Nomor 21 tahun 2015 ientang Tata Cara Pendaftaran Jaminan Fidusia Dan Biaya Pembuatan Akta Jaminan Fidusia).

Permohonan perbaikan sertifikat jaminan fidusia melampirkan : hukumonline.com

(1)Salinan sertifikat Jaminan Fidusia yang akan diperbaiki

(2) Fotokopi bukti pembayaran biaya pendaftaran Jaminan Fidusia

(3) Salinan akta Jaminan Fidusia .(pasal 9 ayat 3 Peraturan Pemerintah Nomor 21 tahun 2015 ientang Tata Cara Pendaftaran Jaminan Fidusia Dan Biaya Pembuatan Akta Jaminan Fidusia).

Permohonan perbaikan sertifikat jaminan fidusia diajukan dalam jangka waktu paling lama 30 (tiga puluh) hari terhitung sejak tanggal sertifikat jaminan fidusia diterbitkan.

Dalam sertifikat jaminan fidusia dicantumkan katakata " DEMI KEADILAN BERDASARKAN KETUHANAN YANG MAHA ESA". Sertifikat jaminan fidusia mempunyai kekuatan eksekutorial yang sama dengan putusan pengadilan yang telah memperoleh kekuatan hukum tetap. Apabila debitor cidera janji, penerima fidusia mempunyai 
hak untuk menjual benda yang menjadi obyek jaminan fidusia atas kekuasaannya sendiri.

\section{b. Biaya Pembuatan Akta Jaminan Fidusia}

Pembuatan akta jaminan fidusia dikenakan biaya yang besarnya ditentukan berdasarkan nilai penjaminan, dengan ketentuan sebagai berikut:

(1) Nilai penjaminan sampai dengan Rp100.000.000,00 (seratus juta rupiah), biaya pembuatan akta paling banyak $2,5 \%$ (dua koma lima perseratus)

(2) Nilai penjaminan di atas Rp100.000.000,00 (seratus juta rupiah) sampai dengan Rp1.000.000.000,00, (satu miliar rupiah), biaya pembuatan akta paling banyak $1,5 \%$ (satu koma lima perseratus)

(3) Nilai penjaminan di atas Rp1.000.000.000,00 (satu miliar rupiah), biaya pembuatan akta berdasarkan kesepakatan antara notaris dengan para pihak, tetapi tidak melebihi $1 \%$ (satu perseratus) dari objek yang dibuatkan aktanya .(pasal 18 Peraturan Pemerintah Nomor 21 tahun 2015 ientang Tata Cara Pendaftaran Jaminan Fidusia Dan Biaya Pembuatan Akta Jaminan Fidusia).

\section{c. Eksekusi Jaminan Fidusia}

Lembaga Jaminan Fidusia emungkinkan kepada para pemberi fidusia untuk menguasai benda yang dijaminkan,untuk melakukan kegiatan usaha yang dibiayai dari pinjaman dengan menggunakan jaminan fidusia. Pada awalnya, benda yang menjadi obyek fidusia terbatas pada kekayaan benda bergerak yang berwujud dalam bentuk peralatan. Akan tetapi dalam perkembangan selanjutnya, benda yang menjadi obyek fidusia termasuk juga kekayaan benda bergerak yang tak berwujud, maupun benda tak bergerak.

Dalam pelaksanaan pembiayaan antara kreditur dan debitur, kadangkala terjadi wanprestasi atau ingkar janji. Maka, ketika debitur ingkar janji pihak kreditur bisa melakukan eksekusi benda yang sudah dijaminkan melalui jaminan fidusia.

Menurut Subekti, yang dimaksud dengan eksekusi adalah upaya dari pihak yang dimenangkan dalam putusan 
guna mendapatkan yang menjadi haknya dengan bantuan kekuatan hukum, memaksa pihak yang dikalahkan untuk melaksanakan putusan (Subekti, 1989 : 128)..

Dengan debitur yang ingkar janji, maka kreditur bisa langsung mengeksekusi benda jaminan yang dijaminkan fidusia. Karena di dalam sertifikat jaminan fidusia memuat ketentuan kata-kata " DEMI KEADILAN BERDASARKAN KETUHANAN YANG MAHA ESA". Dengan kata-kata ini, maka mempunyai kekuatan hukum seperti keputusan pengadilan.

Hal ini sesuia dengan undang-undang nomor 42 tahun 1999 tentang Jaminan Fidusia yang menyatakan, apabila debitor atau pemberi fidusia cidera janji, eksekusi terhadap benda yang menjadi obyek jaminan fidusia dapat dilakukan dengan cara :

(1) Pelaksanaan titel eksekutorial oleh penerima fidusia

(2) Penjualan benda yang menjadi obyek jaminan fidusia atas kekuasaan penerima fidusia sendiri melalui pelelangan umum serta mengambil pelunasan piutangnya dari hasil penjualan

(3) Penjualan di bawah tangan yang dilakukan berdasarkan kesepakatan pemberi dan penerima fidusia jika dengan cara demikian dapat diperoleh harga tertinggi yang menguntungkan para pihak.

Pelaksanaan penjualan di dawah tangan dilakukan setelah lewat waktu 1 (satu) bulan sejak diberitahukan secara tertulis oleh pemberi dan atau penerima fidusia kepada pihak-pihak yang berkepentingan dan diumumkan sedikitnya dalam 2 (dua) surat kabar yang beredar di daerah yang bersangkutan. Dalam undang-undang jaminan fidusia juga diterangkan, bahwa pemberi fidusia wajib menyerahkan benda yang obyek jaminan fidusia dalam rangka pelaksanaan eksekusi jaminan fidusia. Dalam hal Benda yang obyek jaminan fidusia terdiri atas benda perdagangan atau efek yang dapat dijual di pasar atau di bursa, penjualannya dapat dilakukan di tempat-tempat tersebut sesuai dengan peraturan perundang-undangan yang berlaku.

Setiap janji untuk melaksanakan eksekusi terhadap benda yang menjadi obyek jaminan fidusia dengan cara yang bertentangan dengan ketentuan di atas maka batal demi 
hukum. Setiap janji yang memberikan kewenangan kepada penerima fidusia untuk memiliki benda yang menjadi obyek jaminan fidusia apabila debitor cidera janji, batal demi hukum. Dalam hal eksekusi melebihi nilai penjaminan, penerima fidusia wajib mengembalikan kelebihan tersebut kepada pemberi fidusia. Apabila hasil eksekusi tidak mencukupi untuk pelunasan utang, debitor tetap bertanggung jawab atas utang yang belum terbayar.

Akan tetapi, pelaksanaan eksekusi yang dilakukan kreditur melalui jasa debt collector kadangkala menimbulkan masalah baru antara kreditur dengan debitur. Hal ini dikarenakan cara debt collector dalam mengeksekusi barang jaminan fidusia dengan cara kekerasan, intimidasi bahkan dengan cara merampas barang jaminan fidusia dijalan, hal inilah yang menimbulkan perlawanan dari pihak debitur. Untuk itu, kepolisian mebuat keputusan melalui Peraturan Kepala Kepolisian Negara Indonesia Nomor 8 tahun 2011 tentang Pengamanan Eksekusi Jaminan Fidusia.

Eksekusi jaminan fidusia mempunyai kekuatan hukum mengikat yang sama dengan putusan pengadilan yang telah berkekuatan hukum tetap, sehingga memerlukan pengamanan dari Kepolisian Negara Republik Indonesia. Yang dimaksud dengan Pengamanan Eksekusi adalah tindakan kepolisian dalam rangka memberi pengamanan dan perlindungan terhadap pelaksana eksekusi, pemohon eksekusi, termohon eksekusi (tereksekusi) pada saat eksekusi dilaksanakan.

Tujuan peraturan ini meliputi :

(1) Terselenggaranya pelaksanaan eksekusi jaminan Fidusia secara aman, tertib, lancar, dan dapat dipertanggungjawabkan

(2) Terlindunginya keselamatan dan keamanan Penerima Jaminan Fidusia, Pemberi Jaminan Fidusia, dan/atau masyarakat dari perbuatan yang dapat menimbulkan kerugian harta benda dan/atau keselamatan jiwa.

Objek pengamanan jaminan fidusia, meliputi hak jaminan atas :

(1) Benda bergerak yang berwujud

(2) Benda bergerak yang tidak berwujud; dan 
(3) Benda tidak bergerak khususnya bangunan yang tidak dapat dibebani hak tanggungan.

\section{d. Objek pengamanan jaminan fidusia}

Objek pengamanan jaminan fidusia dilaksanakan terhadap benda jaminan yang telah didaftarkan di kantor pendaftaran fidusia berada pada lingkup tugas Kementerian Hukum dan HAM.

Pengamanan terhadap objek jaminan fidusia dapat dilaksanakan dengan persyaratan:

(4) Ada permintaan dari pemohon

(5) Memiliki akta jaminan fidusia

(6) Jaminan fidusia terdaftar pada kantor pendaftaran fidusia

(7) Memiliki sertifikat jaminan fidusia

(8) Jaminan fidusia berada di wilayah negara Indonesia.

\section{e. Permohonan Pengamanan Eksekusi}

Permohonan pengamanan eksekusi diajukan secara tertulis oleh penerima jaminan fidusia atau kuasa hukumnya kepada Kapolda atau Kapolres tempat eksekusi dilaksanakan. Dalam hal permohonan pengamanan eksekusi diajukan oleh kuasa hukum penerima jaminan fidusia, pemohon wajib melampirkan surat kuasa dari penerima jaminan fidusia.

Permohonan pengamanan eksekusi diajukan dengan melampirkan :

(1) Salinan akta jaminan fidusia

(2) Salinan sertifikat jaminan fidusia

(3) Surat peringatan kepada debitur untuk memenuhi kewajibannya. Surat peringatan kepada debitor telah diberikan sebanyak 2 (dua) kali, yang dibuktikan dengan tanda terima.

(4) Identitas pelaksana eksekusi

(5) Surat tugas pelaksanaan eksekusi.

Dalam hal penerima jaminan menunjuk pihak ketiga untuk melaksanakan eksekusi, permohonan pengamanan eksekusi diajukan dengan melampirkan perjanjian kerja sama eksekusi jaminan fidusia antara penerima jaminan dengan pihak ketiga yang ditunjuk. Segala akibat yang ditimbulkan atas perbuatan pihak ketiga dalam pelaksanaan 
eksekusi penerima jaminan fidusia dan pihak ketiga harus bertanggung jawab sesuai dengan ketentuan peraturan perundang-undangan.

Kapolda setelah menerima permohonan pengamanan eksekusi, permohonan diteruskan kepada Kepala Bidang Hukum (Kabidkum) Polda untuk dilakukan penelitian kelengkapan dan keabsahan persyaratan. Kabidkum Polda setelah melakukan penelitian wajib memberikan saran tertulis kepada Kapolda atas terpenuhi atau tidaknya persyaratan permohonan pengamanan eksekusi.

Permohonan pengamanan yang dinyatakan memenuhi syarat, Kapolda memerintahkan Kepala Biro Operasional (Karoops) untuk mempersiapkan, merencanakan, dan melaksanakan pengamanan eksekusi. Dalam hal persyaratan permohonan pengamanan dinyatakan kurang lengkap, Kapolda memberitahukan secara tertulis kepada pemohon untuk melengkapi persyaratan. Dalam hal permohonan pengamanan dinyatakan tidak memenuhi syarat, Kapolda memberitahukan secara tertulis kepada pemohon dengan disertai alasannya.

Kapolres setelah menerima permohonan pengamanan eksekusi, permohonan diteruskan kepada Kepala Sub Bagian Hukum (Kasubbagkum) Polres untuk dilakukan penelitian kelengkapan dan keabsahan. Kasubbagkum Polres setelah melakukan penelitian wajib memberikan saran tertulis kepada Kapolres atas terpenuhi atau tidaknya persyaratan permohonan pengamanan eksekusi.

Permohonan pengamanan yang dinyatakan memenuhi syarat, Kapolres memerintahkan Kepala Bagian Operasional (Kabagops) untuk mempersiapkan, merencanakan, dan melaksanakan pengamanan eksekusi. Dalam hal persyaratan permohonan pengamanan dinyatakan kurang lengkap, Kapolres memberitahukan secara tertulis kepada pemohon untuk melengkapi persyaratan. Dalam hal permohonan pengamanan dinyatakan tidak memenuhi syarat, Kapolres memberitahukan secara tertulis kepada pemohon dengan disertai alasannya.

\section{f. Pelaksanaan Pengamanan Jaminan Fidusia}

Tahapan pelaksanaan pengamanan eksekusi meliputi: 
(1) Tahap persiapan

(2) Tahap pelaksanaan

(3) Tahap pengawasan dan pengendalian.

Tahap persiapan pengamanan eksekusi meliputi :

Pertama: penyusunan perencanaan Penyusunan perencanaan meliputi kegiatan membuat perkiraan intelijen dan menyusun rencana pengamanan eksekusi, yang sekurang-kurangnya memuat :

(1) Waktu pelaksanaan eksekusi

(2) Jumlah personel, kebutuhan anggaran, dan peralatan

(3) Pola pengamanan

(4) Cara bertindak.

Kedua: Rapat koordinasi dilaksanakan sebelum pengamanan eksekusi. Materi rapat koordinasi meliputi:

(1) Penjelasan status hukum jaminan fidusia

(2) Kondisi dan hakikat ancaman di lokasi eksekusi dan sekitarnya

(3) Jumlah personel polri yang dilibatkan

(4) Peralatan yang diperlukan

(5) Penjelasan cara bertindak.

Tahapan pelaksanaan pengamanan eksekusi :

Tahap persiapan pelaksanaan meliputi:

(1) Pengecekan jumlah kekuatan riil personel dan peralatan pengamanan

(2) Memberikan pengarahan kepada personel yang akan melaksanakan pengamanan eksekusi

(3) Menjelaskan cara bertindak dalam pengamanan eksekusi

(4) Pembagian tugas personel pengamanan

(5) Pergeseran pasukan.

Tahap pelaksanaan.

Tahap pelaksanaan dengan cara bertindak :

(1) Melakukan himbauan kepada pihak yang tidak berkepentingan agar meninggalkan lokasi eksekusi

(2) Melakukan pengamanan ketat saat terjadi dialog dan negosiasi antara pelaksana eksekusi dengan tereksekusi

(3) Melindungi pelaksana eksekusi dan/atau pemohon, tereksekusi dan masyarakat yang ada dilokasi

(4) Mengamati, mengawasi, dan menandai orang-orang yang berupaya menghambat atau menghalangi eksekusi 
(5) Mengamankan dan mengawasi benda dan/atau barang yang akan dieksekusi. Pelaksanaan eksekusi yang berjalan aman, tertib, dan lancar, personel pengamanan bersikap pasif.

Dalam hal pelaksanaan eksekusi terjadi perlawanan dari pihak tereksekusi, personel bersikap aktif, dengan cara bertindak:

(1) Mengamankan dan/atau menangkap setiap orang yang melakukan perlawanan atau perbuatan melawan hukum

(2) Melakukan penggeledahan terhadap setiap orang yang dicurigai membawa senjata api, senjata tajam, dan bendabenda berbahaya lainnya

(3) Menyita senjata api, senjata tajam, dan benda-benda berbahaya lainnya yang didapat di lokasi eksekusi

(4) Melokalisir dan/atau melakukan penyekatan akses jalan dari dan menuju lokasi eksekusi.

Dalam hal eskalasi keamanan eksekusi meningkat yang dapat membahayakan anggota dan tidak terkendali, pengendali lapangan segera melaporkan dan meminta bantuan pasukan pengendali masa (Dalmas) atau Brimob Polri kepada :

(1) Kapolres, apabila pengamanan dilaksanakan oleh Polres

(2) Kapolda, apabila pengamanan dilaksanakan oleh Polda.

Kapolres atau Kapolda setelah menerima laporan segera mengirimkan bantuan pasukan ke lokasi eksekusi. Dalam hal termohon eksekusi merasa telah membayar atau melunasi kewajibannya kepada petugas lain yang ditunjuk oleh pemohon eksekusi, yang mengakibatkan timbulnya perselisihan pada saat atau sedang dilaksanakan eksekusi, maka personel Polri yang melaksanakan pengamanan melakukan tindakan sebagai berikut:

(1) Mengadakan pendekatan persuasif antara pemohon dan termohon melalui musyawarah;

(2) Menanyakan dengan sopan dan humanis kepada termohon, untuk menunjukan dokumen pendukung atau bukti pembayaran atau pelunasan;

(3) Mengamankan lingkungan sekitar eksekusi untuk mencegah meningkatnya eskalasi keamanan; dan

(4) Apabila termohon mempunyai bukti pembayaran atau pelunasan yang sah. personel Polri, menunda atau 
menghentikan pelaksanaan eksekusi kemudian membawa dan menyerahkan petugas yang ditugaskan oleh pemohon kepada penyidik Polri untuk penanganan lebih lanjut; dan membawa pihak termohon dan pemohon eksekusi ke kantor kepolisian terdekat untuk penanganan lebih lanjut.

\section{Simpulan}

Dari pembahasan di atas, maka ditarik beberapa kesimpulan, yakni :

Jaminan fidusia adalah hak jaminan atas benda bergerak baik yang berwujud maupun yang tidak berwujud dan benda tidak bergerak khususnya bangunan yang tidak dapat dibebani hak tanggungan sebagaimana dimaksud dalam Undang-Undang Nomor 4 Tahun 1996 tentang Hak Tanggungan yang tetap berada dalam penguasaan Pemberi Fidusia, sebagai agunan bagi pelunasan utang tertentu, yang memberikan kedudukan yang diutamakan kepada Penerima Fidusia terhadap kreditor lainnya.

Tata cara pendaftaran jaminan fidusia adalah dengan cara melakukan permohonan pendaftaran disertai staratsyarat hyang telah ditetapkan ke kantor jaminan fidusia dengan membayar biaya pendaftaran, setelah itu dibuatkan sertifikat jaminan fidusia. Sedangkan biaya pendaftarannya

Nilai penjaminan sampai dengan Rp100.000.000,00 (seratus juta rupiah), biaya pembuatan akta paling banyak 2,5\% (dua koma lima perseratus). Nilai penjaminan di atas Rp100.000.000,00 (seratus juta rupiah) sampai dengan Rp1.000.000.000,00, (satu miliar rupiah), biaya pembuatan akta paling banyak 1,5\% (satu koma lima perseratus). Nilai penjaminan di atas Rp1.000.000.000,00 (satu miliar rupiah), biaya pembuatan akta berdasarkan kesepakatan antara notaris dengan para pihak, tetapi tidak melebihi 1\% (satu perseratus) dari objek yang dibuatkan aktanya.

Eksekusi obyek jaminan fidusia bisa dilaksanakan secara langsung oleh pihak penerima jaminan fidusia atau kreditur apabila pemberi fidusia atau debitur ingkar janji. Apabila dalam pelaksanaan eksekusi mendapatkan 


\section{Jaminan Fidusia di Indonesia}

perlawanan, maka pelaksanaan eksekusi bisa meminta pengamanan dari kepolisian. 
Junaidi Abdullah

\section{Daftar Pustaka}

Undang Undang Nomor 42 Tahun 1999 Tentang Jaminan Fidusia

Peraturan Pemerintah Nomor 86 tahun 2000 tentang Tata Cara Pendaftaran Jaminan Fidusia Dan Biaya Pembuatan Akta Jaminan Fidusia

Peraturan Pemerintah Nomor 21 tahun 2015 tentang Tata Cara Pendaftaran Jaminan Fidusia Dan Biaya Pembuatan Akta Jaminan Fidusia

Peraturan Kepala Kepolisian Negara Indonesia Nomor 8 tahun 2011 tentang Pengamanan Eksekusi Jaminan Fidusia

Hartono Hadisoeprapto, Pokok-Pokok Hukum Perikatan dan Hukum Jaminan, Liberty. Yogyakarta. 2004

Purwahid dan Kashadi, Hukum Jaminana Fidusia, Fakultas Hukum Universitas Diponegoro, Semarang, 2008

R. Subekti, R. Tjitrosoedibio. 1994. Kamus Hukum, Pradnya Paramita, Jakarta.

R. Subekti, Hukum Acara Perdata. 1989. PT Bina Cipta, Bandung. 